\title{
UJI VIABILITAS BIJI KURMA DENGAN LAMA PERENDAMAN AIR KELAPA MUDA
}

\author{
Yesi Harnita $^{1}$, Subagiono ${ }^{2}$ \\ ${ }^{1}$ Alumni Program Studi Agroteknologi Fakultas Pertanian \\ ${ }^{2}$ Dosen Fakultas Pertanian Universitas Muara Bungo \\ Artikel Diterima 18 November 2020, disetujui 10 Januari 2021
}

\begin{abstract}
ABSTRAK
Penelitian ini dilaksanakan di Desa Kapuk Kecamatan Tabir Ulu, dengan ketinggian tempat $\pm 80 \mathrm{~m}$ dpl, jenis Ultisol dengan $\mathrm{pH} 4,5$ (Monografi Desa Kapuk, 2017), Penelitian dilaksanakan pada tanggal 12 Oktober 2019 sampai 28 November 2019. Tujuan penelitian ini adalah untuk mengetahui pengaruh lama perendaman air kelapa dan untuk mengetahui waktu lama perendaman air kelapa yang terbaik terhadap uji viabilitas biji kurma (Phoenix dactylifera L.)

Penelitian ini menggunakan Rancangan Acak Kelompok (RAK) dengan 4 perlakuan yaitu : K0 (tanpa perlakuan), K1 (direndam dengan air kelapa selama 2 jam, K2 (direndam dengan air kelapa selama 4 jam) dan K3 (direndam dengan air kelapa selama 6 jam). Varaibel yang diamati dalam penelitian ini yaitu umur berkecambah (hss), persentase perkecambahan $(\%)$, jumlah kecambah normal (biji), laju perkecambahan (hari) dan panjang radikal $(\mathrm{cm})$. Untuk melihat pengaruh perlakuan terhadap variabel yang diamati maka data yang diperoleh dianalisis secara statistik menggunakan sidik ragam dan apabila hasil analisis berpengaruh nyata maka dilanjutkan dengan uji Duncan New Multiple Range Test (DNMRT) pada tarif
\end{abstract}

\section{Artikel Diterima 18 November 2020, disetujui 10 Januari 2021}

nyata terhadap umur berkecambah (har1), persentase berkecambah (\%), jumlah kecambah normal (biji), dan panjang radikal $(\mathrm{cm})$ tetapi tidak berpengaruh nyata terhadap laju perkecambahan (hari). Perlakuan K1 (direndam 2 jam dengan air kelapa) memberikan hasil terbaik terhadap viabilitas biji kurma (Phoenix dactylifera L.)

Kata kunci : Air Kelapa Muda, Viabilitas, Benih Kurma

\section{PENDAHULUAN}

Kurma (Phoenix dactylifera L.) adalah jenis tanaman palma. Pohon ini termasuk salah satu dari tanaman budidaya tertua di dunia. Buahnya memiliki rasa yang manis merupakan bahan pangan dengan kandungan energi yang tinggi, yaitu $72-88 \%$ kandungan gula. Kurma mengandung zat besi, kalium, kalsium, klorin, magnesium, belerang, sedikit fosfor, 16 asam amino, vitamin A, B1, dan B2. Selain itu kandungan senyawa aktif dari buah kurma yang telah diidentifikasi oleh beberapa peneliti adalah alkaloid, saponin, tanin dan flavonoid. Senyawa-senyawa tersebut terbukti mempunyai prospek cukup baik dalam meningkatkan aktivitas sistem imun (Rosnizar, $d k k .$, 2015).

Sejarah panjang budidaya dan penggunaan Kurma, maka hampir seluruh bagian pohon kurma berguna bagi manusia. Batang pohon dimanfaatkan sebagai kayu atau bahan bakar. Serabut batang dan daun dapat dibuat menjadi tas, keranjang, pelana unta, kabel, tambang, peti kayu, kipas, penutup 
makanan, furniture, kasur, kertas. Daun kering dapat dibuat menjadi atap, penyekat dinding. Tunas pucuk (palm heart) dapat dimakan sebagai salad atau sayur yang dimasak terlebih dahulu. Biji kurma dapat dimanfaatkan sebagai pakan ternak, atau dirangkai menjadi pernak pernik hiasan. Minyak dari biji kurma dapat dibuat menjadi sabun. Buah kurma juga memiliki kegunaan sebagai obat, yakni sebagai astringent untuk mengatasi masalah usus, perut, obat batuk, pereda demam, edema. Di India getah atau eksudat dari kurma digunakan untuk mengobati diare dan akar untuk mengobati sakit gigi (Warasfarm, 2015).

Kurma mempunyai potensi besar sebagai sumber ketahanan pangan, baik karena nilai ekonominya yang tinggi maupun fakta kurma sebagai sumber multi pangan yang bergizi tinggi dalam ketahanan pangan. Pohon kurma termasuk tanaman yang tahan segala cuaca. Pohon ini mampu tumbuh pada rentang suhu yang ekstrim $-15^{\circ} \mathrm{C}$ s/d. $+51{ }^{\circ} \mathrm{C}$. Kurma juga sangat tahan pada kondisi tanah yang marginal, sebagaimana selama ini ditunjukkan dengan tumbuh tegar di padang pasir, namun makin subur tumbuh di Thailand, India, Amerika (California) (Rahmadani, $d k k .$, 2017). Tanaman kurma mempunyai daya tarik untuk dibudidayakan secara meluas di tanah air, karena hasil panen kurma berkisar 15-45 ton /ha/ tahun, dengan asumsi 150 pohon per ha dan hasil $100-300 \mathrm{~kg}$ per pohon/tahun dan cukup hanya dengan menanamnya sekali, akan dapat panen dari tahun ke 5-7 hingga 100 tahun kemudian (seperti tanaman kurma di Timur Tengah dan Coachella Valley USA). Produktifitas yang tinggi dan usia produktif yang panjang ini memberikan hasil kelayakan usaha yang sangat menarik sebagai pilihan investasi dibidang perkebunan (Tomi, 2018),

Disisi lain budidaya dan perkecambahan benih kurma terdapat kendala yaitu kerasnya kulit biji kurma.
Perkecambahan adalah proses pertumbuhan embrio dan komponenkomponen biji yang mempunyai kemampuan untuk tumbuh secara normal menjadi tanaman baru (Ashari, 1995). Perkecambahan tergantung pada viabilitas biji, kondisi lingkungan yang cocok dan pada beberapa tanaman tergantung pada usaha pemecahan dormansi, dan kepekaan bibit muda terhadap penyakit-penyakit tertentu (Harjadi, 1979).

Salah satu langkah alternatif yang dapat diaplikasikan pada pembiakan tanaman Kurma adalah dengan menambahkan air kelapa muda sebagai sumber zat pengatur tumbuh (zpt) alami pada perlakuan awal perkecambahan. Air kelapa adalah salah satu bahan alami, yang mengandung hormon seperti sitokinin, auksin dan giberelin serta senyawa lain yang dapat menstimulasi perkecambahan dan pertumbuhan tanaman. Berdasarkan hasil analisis zpt yang dilakukan oleh Savitri (2005), ternyata dalam air kelapa muda terdapat beberapa zpt, di antaranya; Giberelin $(0,460$ ppm GA3, 0,255 ppm GA5, 0,053 ppm GA7), Sitokinin (0,441 ppm Kinetin, 0,247 ppm Zeatin), dan Auksin (0,237 ppm IAA).

Air kelapa telah lama dikenal sebagai sumber zat tumbuh, yaitu sitokinin. Unsur-unsur yang terdapat dalam air kelapa yaitu unsur makro dan unsur mikro. Unsur makro yang terdapat dalam air kelapa yaitu karbon dan nitrogen berupa karbohidrat (glukosa, fruktosa dan sukrosa) dan protein (asam amino). Unsur mikro diantaranya kalium, natrium, kalsium, magnesium, fosfor dan sulfur. diketahui sebagai sumber yang dapat digunakan untuk perkembangan embrio, (Mumtazanas, 2007 dan Santoso, 2003).

Penelitian yang terkait dengan penggunaan air kelapa untuk memicu pertumbuhan dan perkembangan embrio biji kurma belum ditemukan akan tetapi penelitian Suita dan Naning (2004), yaitu pada benih Kemiri (Aleurites mollucana Wild.) yang direndam air kelapa selama 4 
jam menghasilkan daya berkecambah sebesar 53,33\%.

\section{METODE PENELITIAN}

Penelitian ini dilaksanakan di Desa Kapuk Kecamatan Tabir Ulu, dengan ketinggian tempat $\pm 80 \mathrm{~m} \mathrm{dpl}$, jenis Ultisol dengan pH 4,5 (Monografi Desa Kapuk, 2017), Penelitian dilaksanakan pada tanggal 12 Oktober 2019 sampai tanggal 28 November Desember 2019. Bahan yang digunakan ialah benih kurma varietas ajwa, aquades, pasir dan air kelapa muda. Sedangkan alat yang digunakan adalah kertas saring, kertas tisu, bak perkecambahan, ember, plastik wrap, alat tulis dan alat-alat lainnya yang diperlukan selama penelitian.

Penelitian ini menggunakan Rancangan Acak Kelompok (RAK) dengan 4 perlakuan dan 4 kelompok yaitu : $\mathrm{K} 0=$ Tanpa Perlakuan, $\mathrm{K} 1=$ Direndam dengan air kelapa selama 2 jam, K2 = Direndam dengan air kelapa selama 4 jam, dan $\mathrm{K} 3=$ Direndam dengan air kelapa selama 6 jam

Pelaksanaan penelitian di awali dengan persiapan bak perkecambahan, sebanyak 20 buah, masing-masing bak dibuat dengan ukuran $50 \mathrm{~cm} \times 50 \mathrm{~cm}$. Media perkecambahan yang digunakan adalah pasir. Pasir kemudian dimasukkan ke dalam setiap bak kecambah dengan ketebalan $\pm 5 \mathrm{~cm}$. Sedangkan kurma yang digunakan didapat dari Akar Tani Mandiri Rimbo Bujang yaitu berupa buah kurma varietas Ajwa. Setelah buah kurma disiapkan kemudian biji-biji Kurma dipisahkan dari buahnya, setelah itu biji kurma direndam dengan aquades selama 48 jam kemudian dicuci sampai bersih, setelah itu disaring dan ditiriskan. Setelah biji kurma betul-betul bersih kemudian diberi perlakuan yaitu direndam dalam air kelapa selama 2, 4, dan 6 jam (sesuai dengan perlakuan) dengan entrasi air kelapa $100 \%$.

Setelah biji Kurma diberi perlakuan langkah selanjutnya menyemai benih kurma pada media perkecambahan, dengan cara biji kurma diletakan secara teratur (rapi) di dalam bak perkecambahan yang sudah disiapkan kemudian ditutup pakai plastik wrap, diinkubasi pada suhu ruang dan dijaga kelembabannya dengan menambah $50 \mathrm{ml}$ aquades setiap hari. Jarak antar benih diatur sekitar $5 \mathrm{~cm}$ untuk memudahkan dalam menghitung jumlah biji yang berkecambah.

Variabel yang diamati dalam penelitian ini meliputi : Umur Berkecambah (Hss), persentase perkecambahan (\%), Jumlah kecambah normal, laju perkecambahan (biji/hari), dan panjang radikal $(\mathrm{cm})$. Untuk melihat pengaruh perlakuan terhadap variabel yang diamati maka data yang diperoleh dianalisis secara statistik menggunakan sidik ragam dan apabila hasil analisis berpengaruh nyata maka dilanjutkan dengan uji Duncan New Multiple Range Test (DNMRT) pada tarif nyata 5\% (Steel and Torrie, 1994).

\section{HASIL DAN PEMBAHASAN}

\section{Umur Berkecambah (hss)}

Umur berkecambah diamati setiap hari mulai benih dikecambah-kan. Pada benih berumur 14 hss, hampir semua benih berkecambah, baik yang direndam dengan air kelapa muda maupun yang tidak direndam dengan air kelapa muda, dan untuk pengamatan selanjutnya tidak ada lagi benih kurma yang berkecambah atau benih tidak lagi menampakan ciri-ciri untuk berke-cambah atau benih dianggap mati. Untuk melihat waktu berkecambah benih kurma yang diamati setiap hari, mulai umur 1 hari setelah semai sampai umur 14 hari setelah semai (hss) disajikan dalam gambar 1 berikut 


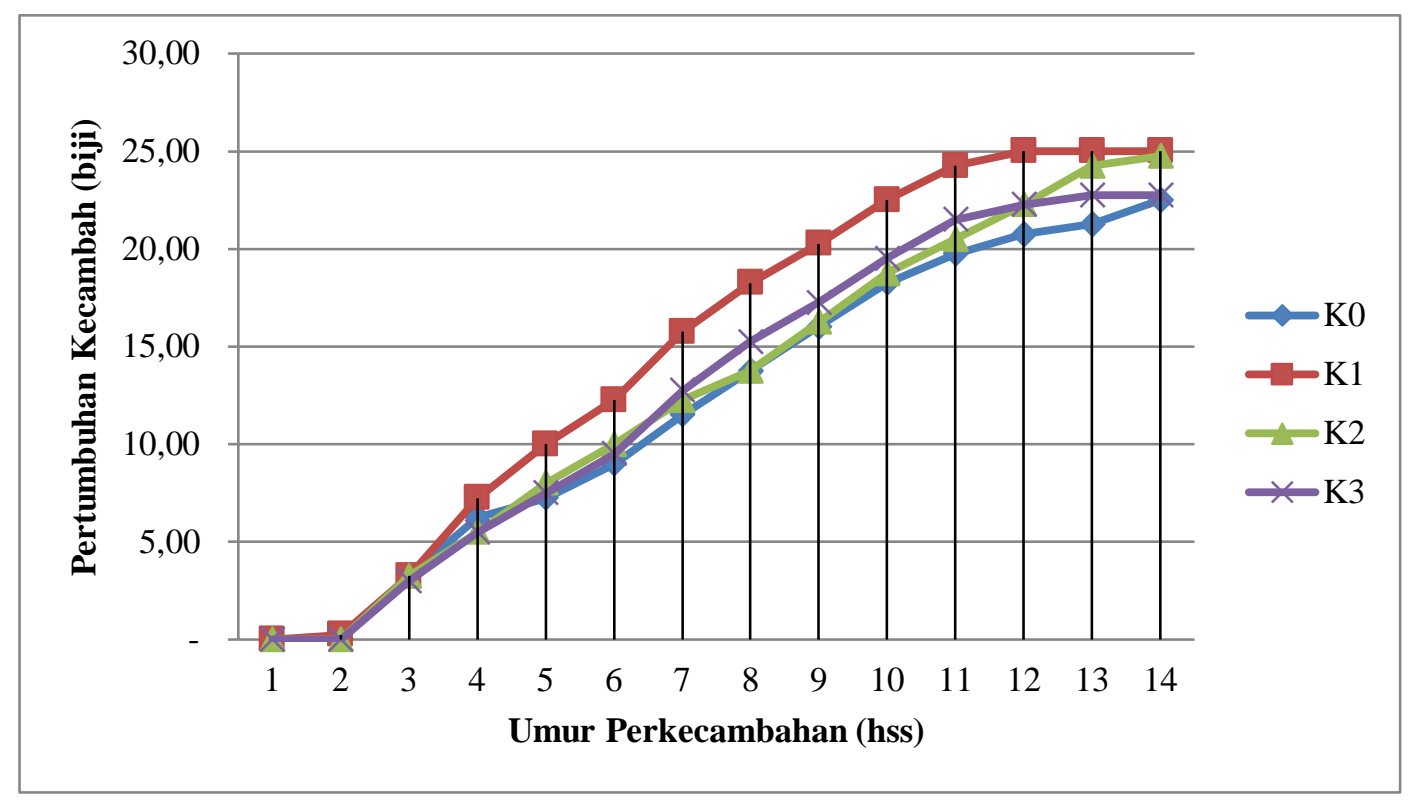

Gambar 1. Grafik pertumbuhan Kecambah Benih Kurma 1 hss - 14 hss

Berdasarkan Gambar grafik pertumbuhan kecambah benih kurma diatas, dapat dilihat bahwa waktu benih kurma mulai berkecambah adalah pada umur 2 hss yaitu pada perendaman benih kurma dengan air kelapa muda selama 2 jam (K1) namun belum terlihat jelas. Pada umur 3 hss benih kurma pada semua perlakuan dapat berkecambah dengan jumlah yang hampir sama. Pertambahan jumlah benih yang berkecambah pada umur 4 hss sampai akhir berkecambah yaitu 14 hss tidak sama setiap perlakuan, dimana perlakuan $\mathrm{K} 2$, dominan lebih banyak tumbuh setiap harinya dan sampai umur 11 hss pada perlakuan K2 semua benih kurma yang diuji dapat berkecambah. Pada perlakuan K0, K2 dan K3, pertumbuhan benih kurma yang berkecambah setiap hari terlihat hampir sama sampai umur 14 hss, dimana hari ke14 setelah semai tidak semua benih kurma berkecam-bah baik pada perlakuan K0, K2 mapun K3.

Berdasarkan hasil analisis ragam menunjukkan bahwa lama perendaman dengan air kelapa muda berpengaruh nyata terhadap umur berkecambah benih kurma. Rataan umur berkecambah benih kurma pada masing-masing lama perenda-man dengan air kelapa muda dapat dilihat pada Tabel 1.

Tabel 1. Pengaruh Lama Perendaman dengan Air Kelapa Muda Terhadap Umur Berkecambah Kurma

\begin{tabular}{cc}
\hline Perlakuan & $\begin{array}{c}\text { Rata-Rata } \\
\text { (hss) }\end{array}$ \\
\hline K0 & $13,25 \mathrm{a}$ \\
K1 & $11,25 \mathrm{~b}$ \\
K2 & $13,50 \mathrm{a}$ \\
K3 & $11,25 \mathrm{ab}$ \\
\hline
\end{tabular}

$\mathrm{KK}=\mathbf{6 , 8 0} \%$

Keterangan : Angka-angka yang di ikuti oleh huruf kecil yang berbeda pada kolom yang sama menunjukkan berbeda nyata menurut uji DNMRT pada taraf $5 \%$.

Tabel 1 menunjukan bahwa umur berkecambah pada perlakuan K0 tidak berbeda dengan perlakuan $\mathrm{K} 2$ dan $\mathrm{K} 3$ tapi berbeda dengan K1. Hasil penelitian menunjukan bahwa umur berkecambah paling lama adalah $\mathrm{K} 2$ yaitu 13,50 hari dan tidak beda dengan perlakuan K0 dan K3 sedangkan umur berkecambah benih kurma tercepat adalah perlakuan K1 yaitu 11,25 hari sehingga perlakuan K1 merupakan perlakuan terbaik. Hal ini berarti bahwa perendaman kurma dalam $100 \%$ air kelapa muda selama 2 jam (K2) 
akan memperce-pat umur berkecambah kurma yang diduga karena penyerapan zpt yang terkandung dalam air kelapa muda selama 2 jam sesuai dengan kebu-tuhan biji yang mengakibatkan meningkatkan kegiatan metabolisme di dalam biji, sehingga biji lebih mudah dan cepat untuk tumbuh dan jika waktu perendaman ditingkatkan maka akan terjadi ketidak seimba-ngan metabolisme dalam benih kurma.

Hal ini sesuai dengan pernya-taan Patma $d k k$. (2013), bahwa secara alami dalam tubuh tanaman sudah mengandung sejumlah zpt bagi pertumbuhan dan perkembangannya, tetapi penambahan ZPT dari luar dapat mempercepat pembentukan akar, tunas, dan tingkat pertumbuhan tanaman. Diperkuat oleh Zuhro $d k k$, (2017), yang menyatakan bahwa pada konsentrasi optimal, penyerapan zpt yang terkandung dalam air kelapa muda diasumsikan akan semakin proporsional atau sesuai dengan kebutuhan biji. Dan pada konsentrasi yang lebih tinggi, dapat mengganggu keseimbangan sistem metabolisme biji sehingga justru dapat menghambat pertumbuhan biji.

\section{Persentase Perkecambahan (\%)}

Hasil analisis ragam menun-jukkan bahwa lama perendaman dengan air kelapa berpengaruh nyata terhadap persentase perkecambahan (\%) benih kurma. Rataan persentase perkecambahan benih kurma pada masing-masing perlakuan lama perendaman dengan air kelapa dapat dilihat pada Tabel 2.

Tabel 2. Pengaruh Lama Perendaman dengan Air Kelapa Terha-dap persentase Perkecambahan Benih Kurma

\begin{tabular}{cr}
\hline Perlakuan & $\begin{array}{c}\text { Rata-Rata } \\
(\%)\end{array}$ \\
\hline K0 & $90,00 \mathrm{~b}$ \\
K1 & $100,00 \mathrm{a}$ \\
K2 & $99,00 \mathrm{a}$ \\
K3 & $91,00 \mathrm{~b}$
\end{tabular}

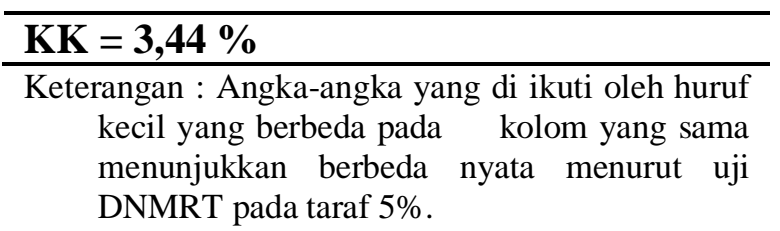

Tabel 2 menunjukan bahwa persentase perkecambahan benih kurma pada perlakuan K0 tidak berbeda dengan perlakuan K3 tapi berbeda dengan $\mathrm{K} 1$ dan K2. Hasil penelitian menunjukan bahwa per-sentase perkecambahan benih kurma paling sedikit adalah K0 yaitu $90 \%$ dan tidak beda dengan perlakuan K3, sedangkan persentase perkecamba-han benih kurma yang paling banyak adalah perlakuan K1 yaitu $100 \%$ dan tidak berbeda dengan $\mathrm{K} 2$ sehingga perlakuan $\mathrm{K} 1$ merupakan perlakuan terbaik terhadap persentase perke-cambahan benih kurma. Hal ini diduga perendaman 2 jam dengan air kelapa dapat diserap sempurna oleh sehingga mendorong pembentukan sel yang berdampak pada perke-cambahan benih kurma, jika lama perendaman di tingkatkan maka auksin yang terserap berlebih sehingga menghambat potensi tumbuh benih kurma yang diamati sehingga perkecambahan benih akan menurun.

Tampubolon $\quad d k k \quad$ (2016), menyatakan air kelapa muda yang terserap sesuai dengan biji untuk perkecambahan otomatis hormon-hormon pertumbuhan yang terserap pun dengan kadar yang sesuai seperti hormon sitokinin, auksin dan gibere-lin serta senyawa lain yang dapat mempercepat daya kecambah, sehingga menghasilkan perkecamba-han biji yang terbanyak. Pernyataan ini diperkuat Dwijaseputro (2004), yang menyatakan bahwa pemberian ZPT pada tanaman hendaknya pada konsentrasi optimal yaitu konsentrasi dimana benih mampu merespon dengan baik. Konsentrasi yang terlalu rendah tidak akan menun-jukkan perubahan signifikan pada tanaman, sedangkan pemberian pada konsentrasi yang terlalu tinggi justru akan berdampak 
pada penurunan. Karena ZPT pada konsentrasi yang tinggi akan bersifat racun bagi tanaman. Menurut Pamungkas (2009), hormon auksin akan mening-katkan pertumbuhan sampai menca-pai konsentrasi yang optimal. Apa-bila konsentrasi yang diberikan melebihi konsentrasi yang optimal, maka akan mengganggu metabolis-me dan perkembangan tumbuhan sehingga menurunkan pertumbuhan.

Untuk melihat persentase perkecambahan benih kurma yang diamati setiap hari, mulai umur 7 hari setelah semai sampai umur 14 hari setelah semai (hss) disajikan dalam gambar 2 berikut

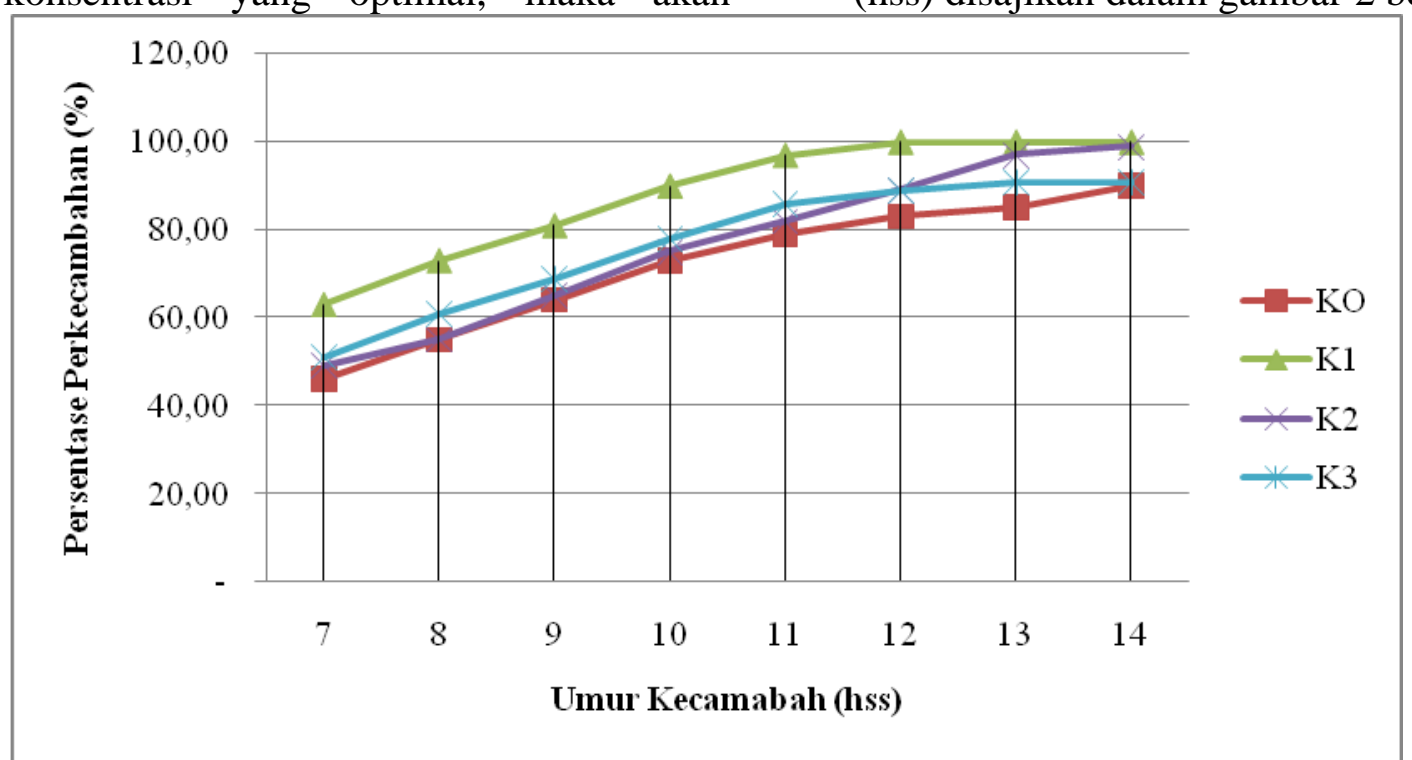

Gambar 2. Grafik Persentase Perkecambahan Benih Kurma Umur 7 hss - 14 hss

Berdasarkan Gambar grafik persentase perkecambahan benih kurma diatas, dapat dilihat bahwa persentase perkecambahan benih kurma pada umur 7 hss tidak sama setiap perlakuan pada perlakuan K1 terlihat jelas lebih banyak dan terus berkecambah sampai $100 \%$ pada umur 12 hss, pada umur 13 hss sampai 14 hss pada perlakuan $\mathrm{K} 2$ persentase perkecambahan mendekati persentase perkecambahan K1 dengan jumlah $99 \%$ benih berkecambah dan perlakuan $\mathrm{K} 0$ dan K4 terlihat sama.

\section{Jumlah Kecambah Normal (biji)}

Hasil analisis ragam menunjukkan bahwa lama perendaman dengan air kelapa berpengaruh nyata terhadap jumlah kecambah normal benih kurma. Rataan jumlah kecambah normal benih kurma pada masing-masing perlakuan lama perendaman dengan air kelapa dapat dilihat pada Tabel 3.

Tabel 3. Pengaruh Lama Perendaman dengan Air Kelapa Terhadap Jumlah Kecambah Normal Benih Kurma

\begin{tabular}{cc}
\hline Perlakuan & $\begin{array}{c}\text { Rata-Rata } \\
\text { (biji) }\end{array}$ \\
\hline K0 & $20,00 \mathrm{~b}$ \\
K1 & $24,00 \mathrm{a}$ \\
K2 & $22,75 \mathrm{a}$ \\
K3 & $20,00 \mathrm{~b}$ \\
\hline
\end{tabular}

KK $=5,66 \%$

Keterangan : Angka-angka yang di ikuti oleh huruf kecil yang berbeda pada kolom yang sama menunjukkan berbeda nyata menurut uji DNMRT pada taraf $5 \%$.

Tabel 3 menunjukan bahwa jumlah kecambah normal benih kurma pada 
perlakuan K0 tidak berbeda dengan perlakuan $\mathrm{K} 3$ tapi berbeda dengan $\mathrm{K} 1$ dan K2. Hasil penelitian menunjukan bahwa rataan jumlah kecambah normal benih kurma paling sedikit adalah K0 yaitu 20 biji dan tidak beda dengan perlakuan K3, sedangkan rataan jumlah kecambah normal benih kurma yang paling banyak adalah perlakuan K1 yaitu 24 biji dan tidak berbeda dengan K2 sehingga perlakuan K1 merupakan perlakuan terbaik terhadap persentase perkecambahan benih kurma. Hal ini diduga sitokinin tersedia dan sudah mencukupi pada perendaman selama 2 jam dan jika ditingkatkan menjadi 6 jam akan merusak benih kurma.

Heddy (1996) menyatakan bahwa senyawa sitokinin dalam konsentrasi rendah dapat mengatur proses fisiologis tumbuhan. Hormon ini mempengaruhi asam nukleat untuk sintesis enzim dan mengatur aktifitas enzim sitokinin juga berperan dalam pembelahan sel sehingga radikula dapat terdorong menembus endosperm. Sedangkan menurut Kamil (2011), syarat benih bermutu tinggi adalah benih yang mempunyai daya kecambah minimal $80 \%$ dan pada umumnya, apabila kebutuhan untuk perkecambahan seperti air, suhu, oksigen, dan cahaya terpenuhi, biji bermutu tinggi (high vigor) akan menghasilkan kecambah atau bibit yang normal (normal seedling). Lebih lanjut Sutopo (2011), menyatakan bahwa biji dikatakan tumbuh normal apabila batangnya tumbuh dengan baik yaitu memiliki hipokotil yang panjang, tumbuh baik dan kotiledon paling sedikit ada yang masih melekat pada biji.

\section{Laju Perkecambahan (hari)}

Berdasarkan hasil analisis ragam menunjukkan bahwa lama perendaman dengan air kelapa tidak berpengaruh nyata terhadap laju perkecambahan benih kurma. Rataan persentase laju perkecambahan benih kurma pada masing-masing perlakuan lama perendaman dengan air kelapa dapat dilihat pada Tabel 4.

Tabel 4. Pengaruh Lama Perendaman dengan Air Kelapa Terha-dap Laju Perkecambahan Benih Kurma

\begin{tabular}{cc}
\hline Perlakuan & $\begin{array}{c}\text { Rata-Rata } \\
\text { (hari) }\end{array}$ \\
\hline K0 & 7,45 \\
K1 & 6,64 \\
K2 & 7,75 \\
K3 & 7,11 \\
\hline
\end{tabular}

KK $=7,61 \%$

Keterangan : Perlakuan tidak berpengaruh nyata terhadap persentase perkecam-bahan $(\mathrm{P}>0,05)$

Tabel 4 menunjukan bahwa lama perendaman dengan air kelapa tidak berpengaruh nyata terhadap laju perkecambahan benih kurma. Hal ini diduga faktor genetik lebih berperan.

Sutopo (2011), menyatakan bahwa faktor genetik biji juga sangat berperan dalam proses perkecamba-han biji yang menentukan cepat lambatnya proses perkecambahan biji maupun mampu tidaknya biji berkecambah (daya viabilitas biji). Susilowarno, (2007) menyatakan bahwa berdasarkan faktor-faktor yang menstimulasi perkecambahan dapat disimpulkan bahwa air, suhu, oksigen dan kelembaban sebagai faktor eksternal, sementara enzim dan hormon sebagai faktor internal mempengaruhi kecepatan perkecam-bahan. Siregar (2010) menyatakan kecepatan perkecambahan dipenga-ruhi oleh faktor lingkungan seperti tanah dan iklim mikro. Menurut Gairola (2011), juga menyebutkan bahwa perkecambahan ditentukan oleh kondisi ekologi habitat, tergan-tung pada kondisi lingkungan perkecambahan.

Sutopo (2011) juga menyata-kan bahwa laju perkecambahan mencerminkan kekuatan tumbuhnya. Semakin rendah laju 
perkecambahan akan menunjukkan semakin cepat benih berkecambah dan semakin kuat pertumbuhan kecambah. Kurnia dkk., (2019) melaporkan peningkatan ke-kuatan tumbuh tanaman disebabkan oleh peningkatan penyerapan oksi-gen dan efisiensi memobilisasi nutrisi dari kotiledon ke pusat embrio didalam benih

\section{Panjang Radikal (cm)}

Berdasarkan hasil analisis ragam menunjukkan bahwa lama perendaman dengan air kelapa berpengaruh nyata terhadap panjang radikal benih kurma. Rataan panjang radikal benih kurma benih kurma pada masing-masing perlakuan lama perendaman dengan air kelapa dapat dilihat pada Tabel 5.

Tabel 5. Pengaruh Lama Perendaman dengan Air Kelapa Terhadap Panjang Radikal Benih Kurma

\begin{tabular}{cc}
\hline Perlakuan & $\begin{array}{c}\text { Rata-Rata } \\
(\mathbf{c m})\end{array}$ \\
\hline K0 & $4,35 \mathrm{c}$ \\
K1 & $6,90 \mathrm{a}$ \\
K2 & $5,79 \mathrm{~b}$ \\
K3 & $4,08 \mathrm{c}$ \\
\hline
\end{tabular}

$\mathrm{KK}=\mathbf{1 1 , 6 1 \%}$

Keterangan : Angka-angka yang di ikuti oleh huruf kecil yang berbeda pada kolom yang sama menunjukkan berbeda nyata menurut uji DNMRT pada taraf $5 \%$.

Tabel 5 menunjukan bahwa panjang radikal benih kurma pada perlakuan K0 tidak berbeda dengan perlakuan $\mathrm{K} 3$ tapi berbeda dengan $\mathrm{K} 1$ dan K2. Hasil penelitian menunjukan bahwa panjang radikal benih kurma paling pendek adalah K3 yaitu 4,08 cm dan tidak beda dengan perlakuan $\mathrm{K} 0$, sedangkan panjang radikal benih kurma yang paling panjang adalah perlakuan K1 yaitu 6,90 dan berbeda dengan semua perlakuan sehingga perlakuan K1 merupakan perlakuan terbaik terha-dap panjang radikal benih kurma. Hal ini diduga ZPT (sitokinin, auksin maupun Giberalin) yang terdapat pada perendaman 2 jam dengan air kelapa muda mampu merangsang pertumbuhan tanaman yang memacu proses pembelahan dan pemanjangan sel.

Abidin (2009), menyatakan bahwa auksin mempunyai kemam-puan dalam perpanjangan sel tana-man, giberelin dapat menstimulasi pembelahan sel dan pemanjangan sel atau keduanya, sitokinin mendukung terjadinya pembelahan sel sehingga dapat meningkatkan pertumbuhan pada tanaman. Sedangkan menurut Wattimena (1992), kombinasi sito-kinin dan auksin mampu mendorong pembelahan sel dan menentukan arah diferensiasi sel tanaman. Lebih lanjut menurut Salisbury dan Ross (2005), pada konsentrasi rendah sitokinin dapat memacu pembelahan dan pemanjangan sel yang akhirnya akan memacu pertumbuhan sedangkan pada konsentrasi tinggi dapat menghambat pertumbuhan tanaman.

\section{KESIMPULAN DAN SARAN}

\section{Kesimpulan}

Berdasarkan hasil penelitian dan pembahasan diatas maka dapat diambil kesimpulan sebagai berikut :

1. Lama perendaman pada air kelapa berpengaruh nyata terha-dap umur berkecambah (hari), persentase berkecambah (\%), jumlah kecambah normal (biji), dan panjang radikal $(\mathrm{cm})$ tetapi tidak berpengaruh nyata terhadap laju perkecambahan (biji/ hari)

2. Perlakuan K1 (direndam 2 jam dengan air kelapa) memberikan hasil terbaik terhadap viabilitas biji kurma (Phoenix dactylifera L.)

\section{Saran}

Untuk mendapatkan viabilitas biji kurma (Phoenix dactylifera L.) yang maksimal disarankan melaku-kan perendaman dengan air kelapa selama 2 jam dan juga disarankan melakukan penelitian lebih lanjut uji viabilitas dengan perlakuan perendaman dengan air biasa. 


\section{DAFTAR PUSTAKA}

Abidin, Z. 2009. Abidin. 2009. Dasardasar tentang Zat Pengatur Tumbuh. Angkasa Bandung.

Ashari, S. 1995. Hortikultura Aspek Budidaya. UI Press. Jakarta.

Dwijasaputro. 2004. Fisiologis Tumbuhan. Gadjah Mada Press. Yogyakarta

Gairola KC, AR Nautiyal and AK Dwivedi. 2011. Effect of Temperatures and germination Media on Seed Germination of Jatropha curcas Linn. Adv. Biores.2 [2].

Harjadi, S.S. 1979. Pengantar Agronomi. PT. Gramedia Jakarta

Heddy S. 1996. Hormon Tumbuhan. Raja Grafindo Persada. Jakarta.

Kamil, J. 2011. Teknologi Benih. Penerbit Kanisius. Yogya-karta

Kurnia. D., F. Okky dan P. Putra. 2019. Pemeraman Benih Gandum (Triticum aestivum L.) untuk Meningkatkan Kua-litas Perkecambahan Pada Kondisi Cekaman Kering. AGRIC Vol. 31, No. 1

Mumtazanas. 2007. Multikhasiat Air Kelapa. wordpress.com/2007/ 05/29/multikhasiat-air-kela-pa/$53 \mathrm{k}-$

Pamungkas, T. Febriani., S.Darmanti dan B. Raharjo. 2009. Penga-ruh Pemberian Air Kelapa Terhadap Pertum-buhan Ta-naman Anggrek dan Kantong Semar (Paphiopedilum su-pardi braem dan loeb) Pada Media Khudson secara In vitro.

Patma, U., Lolli A. P.P., Lutfi A. M. S. 2013. Respon Media Tanam dan Pemberian Auksin Asam Asetat Naftalen pada Pembibitan Aren (Arenga pinnata Merr.). Jurnal Online Agroteknologi .Vol 1. No.2.

Rahmadani, R.A, S. Bulkis dan M.A. Budiman. 2017. Potensi Budidaya Kurma Di Indo-nesia Ditinjau Dari Perspektif Ekonomis Dan Ekologis. Prosiding Seminar Nasional ASBIS 2017. Politeknik Negeri Banjarmasin.

Rosnizar, K. Eriani, I.M. Ramli dan F. Muliani. 2015. Uji Efek Imunostimulan Buah Kurma (Phoenix dactylifera) Pada Mencit Jantan (Mus muscu-lus) Galur Balb/C. Diunduh 24 Juni 2019

Salisbury.F.B., dan C.W. Ross. 2005. Fisiologi Tumbuhan (terje-mahan). Penerbit Institut Teknologi Bandung Press. Bandung.

Savitri, S.V.H. 2005. Induksi akar stek batang Sambung Nyawa (Gynura drocumbens (Lour) Merr.) Menggunakan Air Kelapa. Institut Pertanian Bogor. Bogor.

Steel, R, G, D dan Torrie, J, H. 1994. Prinsip dan Prosedur Statisti-ka Suatu Pendekatan BIO Metrik. Penerbit PT. Grame-dia Pustaka Utama, Jakarta.

Suita E dan Naning Y. 2004. Penga-ruh Skarifikasi Terha-dap Daya Berkecamba Benih Ke-miri. Penelitian Kehutanan 02 
Susilowarno. 2007. Biologi untuk SMA/MA Kelas XII. Grasindo. Jakarta.

Sutopo, L. 2011. Teknologi Benih. Cetakan Ke VII. Penerbit Rineka Cipta. Jakarta

Tampubolon. A., M. Mardiansyah dan T. Arlita. 2016. Perenda-man Benih Saga (Adenan-thera pavonina L.) Dengan Berbagai Konsentrasi Air Ke-lapa Untuk Meningkatkan Kualitas Kecambah. om Faperta UR Vol 3 No 1. Diunduh Februari 2020

Tomi. F. 2018. Keunggulan Mena-nam Kurma Di Indonesia. https://www.bibit-buahku. com /blog/keunggulan-mena-namkurma-di-indonesia. Diuduh 19 Juni 2019

Warasfarm, 2015. Belajar Budidaya Pohon Kurma Di Indonesia. https://warasfarm.wordpress.com/2 015/01/08/belajar-budi-dayapohon-kurma-di-indonesia/. Diunduh 25 Juni 2019

Wattimena, G.A. 1992. Bioteknologi Tanaman. Departemen Pendi-dikan dan Kebudayaan, Di-rektorat Jenderal Pendidikan Tinggi, Pusat Antar Univer-sitas Bioteknologi IPB, Bogor.

Zuhro, F., H.U.Hasanah dan Sukadi. 2017. Aplikasi Air Kelapa Muda dan Pupuk Kascing pada Perkecambahan Biji Palem Merah (Cyrtostachys lakka Becc). urnal Ilmu Dasar Vol. 18 No. 1. Diunduh Februari. 2020. 